\title{
History of the pineal gland
}

\author{
Mohammadali M. Shoja • Lauren D. Hoepfner • \\ Paul S. Agutter • Rajani Singh • R. Shane Tubbs
}

Received: 27 January 2015 / Accepted: 3 February 2015 /Published online: 11 March 2015

(C) Springer-Verlag Berlin Heidelberg 2015

\section{Introduction}

There is a long and culturally diverse history regarding the pineal gland $[9,10,14,20,21]$; most of which have been highly mystical. Famously, Descartes (1594-1650) regarded the pineal gland as the point of contact between the soul, body, and the place where our thoughts are formed $[5,7,17,22]$ (Fig. 1 and cover figure). This conjecture has present-day counterparts such as Strassman's claim that the gland produces N,N-dimethyltryptamine, an intermediate in melatonin synthesis, which Strassman describes as "the spirit molecule" and believes to be involved in dreaming [19]. Other extraordinary speculations include those of pharaonic Egypt, where the pineal was equated with the eye of Horus [13]. Additionally, the "third eye" of Hindu spiritual enlightenment is described as originally being a third eyeball that atrophied into the pineal gland [4].

\section{Greek accounts of the pineal gland}

The earliest surviving description of the pineal in the Greek tradition was in the 8th book of Galen's On the

M. M. Shoja $\cdot$ L. D. Hoepfner $\cdot$ R. S. Tubbs $(\bowtie)$

Pediatric Neurosurgery, Children's of Alabama, 1600 7th Ave South,

Lowder 400, Birmingham, AL 35233, USA

e-mail: shane.tubbs@childrensal.org

\section{P. S. Agutter}

Theoretical Medicine and Biology Group, Glossop, Derbyshire, UK

R. Singh

Department of Anatomy, AIIMS, Rishikesh, Uttrakhand, India usefulness of the parts of the body in which he gave it the name "pineal" because of its resemblance to pine nuts

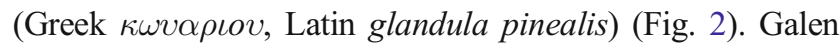
commented that the gland was known before him and considered it a "gland" partly because of its appearance and partly because it appeared to support local blood vessels, which he believed to be the function of all glands [12]. He worked to refute an opinion, apparently current at the time but of unknown origin, that the pineal gland regulated the flow of psychic pneuma between the middle and posterior brain ventricles, similar to the way in which the pylorus regulates the movement of food from the esophagus to the stomach [8]. Galen regarded the lateral ventricles of the brain as a single paired anterior ventricle, so he dubbed the third ventricle "middle" and the fourth "posterior". Although he accepted that the ventricles contained the intangible pneuma, Galen disputed the "valve" function of the pineal gland because (1) it is attached to the outside of the brain and (2) it cannot move on its own. Galen argued that the "worm-like appendage" of the cerebellum was better suited to act as the valve that regulated psychic pneuma flow [8].

Subsequent ideas were built upon Galen's. According to the 5th century compiler Aetios [16], in the late 4th century CE, Posidonius of Byzantium and Nemesius of Emesa attributed imagination to the anterior ventricle, reason to the middle ventricle, and memory to the hind part of the brain [11]. This view persisted, with variants, until the mid 16th century CE, when Niccolò Massa (1536) found that the ventricles were filled with fluid instead of psychic pneuma, and Vesalius (1543) dismissed the notions of ventricular localization and the flow of spirits being controlled by valves $[8,15]$. 
Fig. 1 and cover figure From Descartes' La Dioptrique

(Dioptrics) published in 1637 and showing the pineal gland and its connections to the nervous system. Note the nerves of the arm and optic nerves having connections to the enlarged pineal gland

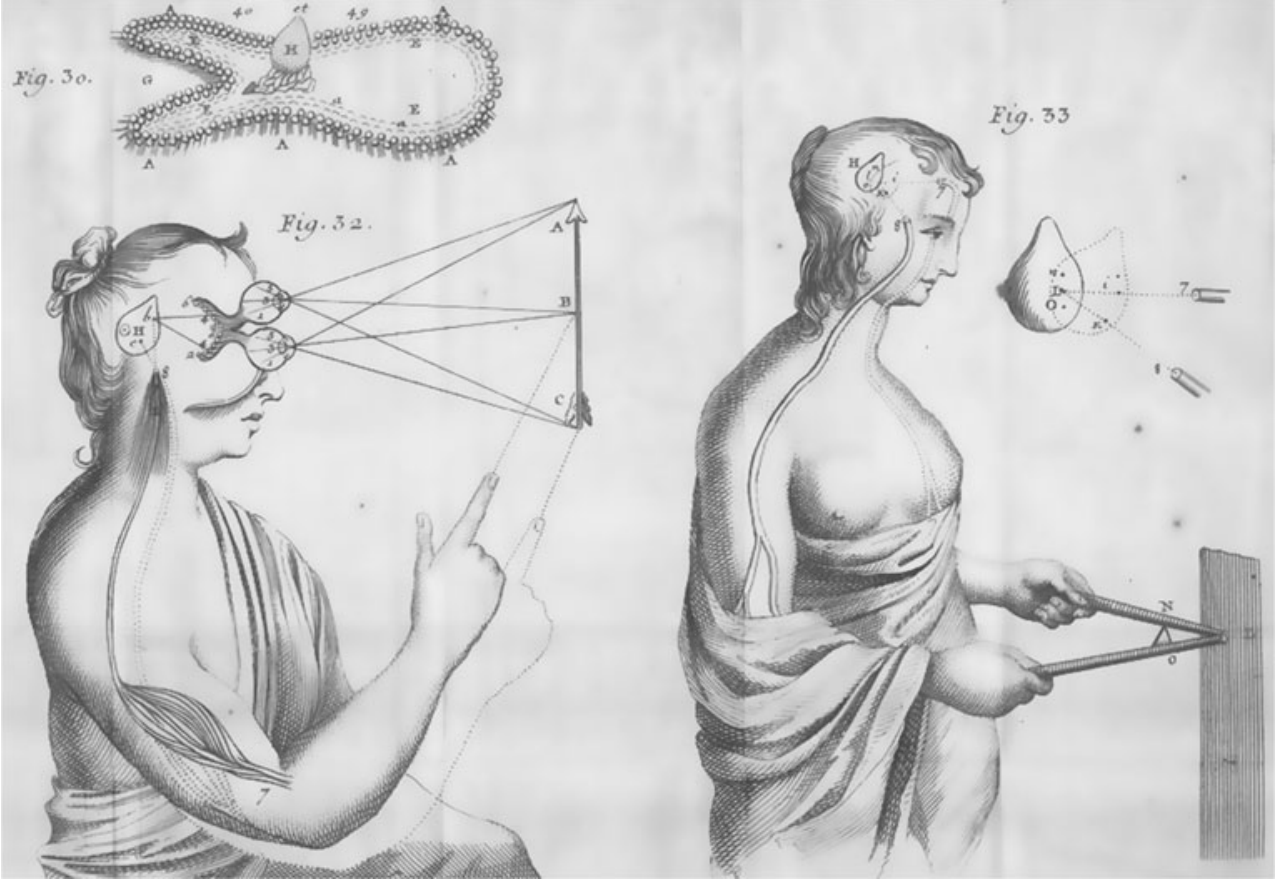

\section{Medieval European accounts}

In many medieval writings on the subject, there seems to have been confusion between the pineal gland and the vermiform structure in the cerebellum. Galen believed that the vermiform structure was the true regulator of psychic pneuma flow between the middle and posterior ventricles, which was then combined with the ventricular localization doctrine of Nemesius and Posidonius. Examples of this combined theory include On the difference between spirit and soul by the Melkite physician Qusta ibn Luqa (864-923CE) in which he stated

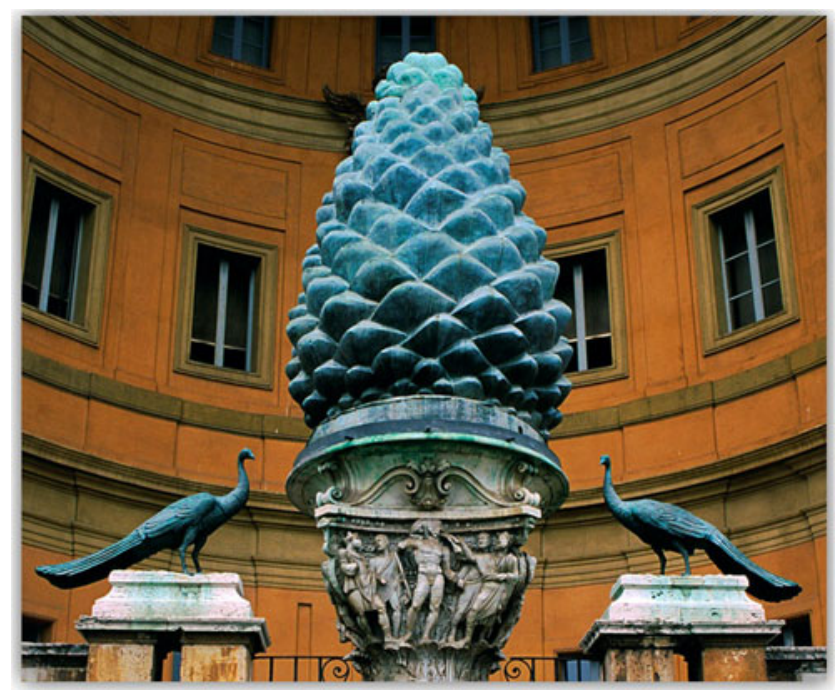

Fig. 2 Roman bronze called the Fontana della Pigna located in the Vatican courtyard and the largest pine cone statue in the world that people who wanted to remember should look up in order to raise the worm-like appendage (pineal gland) and allow for memory retrieval from the posterior ventricle [8]. However, the vermiform structure was termed pinea by Vincent do Beauvais in the 13th century CE and Publicius in 1492 [1, $8]$, thus causing continued confusion between the pineal gland and the vermiform structure. Moreover, Mondino dei Luzzi (1306) described the choroid plexus as a worm that opens and closes the canal between the anterior and middle ventricles. Therefore, by the late Middle Ages in Europe, three "worms" were described in the brain: the vermis of the cerebellum, the choroid plexus, and the pineal gland.

\section{Descartes}

In view of the discoveries by Massa and Vesalius a century earlier, and indeed of the more accurate observations by Galen (see above), Descartes' remarks about the pineal gland were in many ways ill-informed. He said it was suspended in the middle of the ventricles, a point on which Galen would have corrected him [18]. Remarks about the pineal gland were found in his La Dioptrique (Dioptrics) (1637) where he described "a certain small gland in the middle of the ventricles" as the seat of the sensus communis. He maintained the view that it was full of psychic pneuma and ascribed this to the arteries that supplied the structure; but Galen had recognized that the main vasculature to the gland is venous. Descartes believed that the animal spirits inflate the ventricles, thus communicating the soul's spiritual autonomy to the mechanism of 
the body. His notion that there is a physical point of contact between the soul and the body broadly echoes the opinions of Augustine [2] and Thomas Aquinas [3].

Shortly after the death of Descartes, Thomas Willis wrote, "We can scarce believe this [the pineal gland] to be the seat of the Soul, or its chief Faculties to arise from it; because Animals, which seem to be almost quite destitute of Imagination, Memory, and other superior Powers of the Soul, have this Glandula or Kernel large and fair enough" [23] (Fig. 3).

\section{Modern views of the pineal gland}

There was little or no progress towards a modern scientific understanding of the pineal gland until the later part of the 19th century [23] (Fig. 4). In this period, the notion that the pineal is an evolutionary relic of a dorsal third eye was proposed. Additionally, the hypothesis that the pineal is an endocrine gland was also proposed. In 1958, it was determined that the pineal gland secretes melatonin, which regulates the circadian rhythm [6]. While a modified theory of the pineal as a vestige of a third eye is still accepted today, the hypothesis that it is an endocrine organ was fully established in the 20th century in the wake of the isolation of melatonin as a pineal secretory product in 1958 by Lerner and colleagues [8].

The history of the pineal gland is long with its function only being elucidated in the 20th century. Earlier accounts of the gland were based on superstition and a misunderstanding

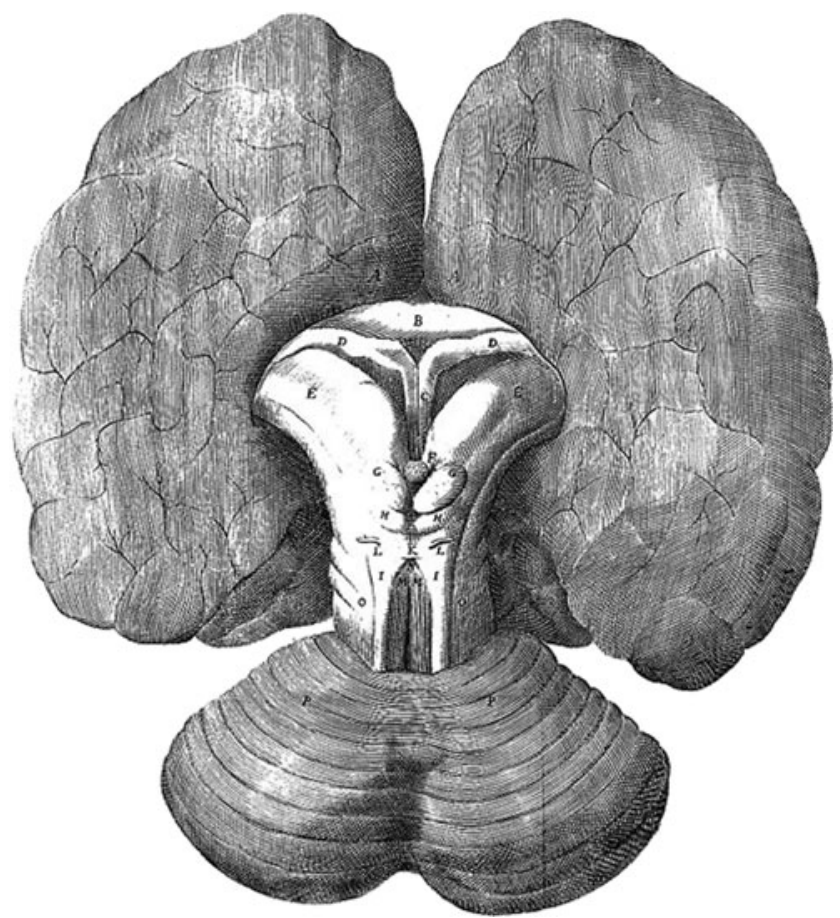

Fig. 3 Drawing of the brain illustrating the pineal gland from Willis' Cerebri Anatome published in 1664. Note the depicted gland above the corpora quadrigemina

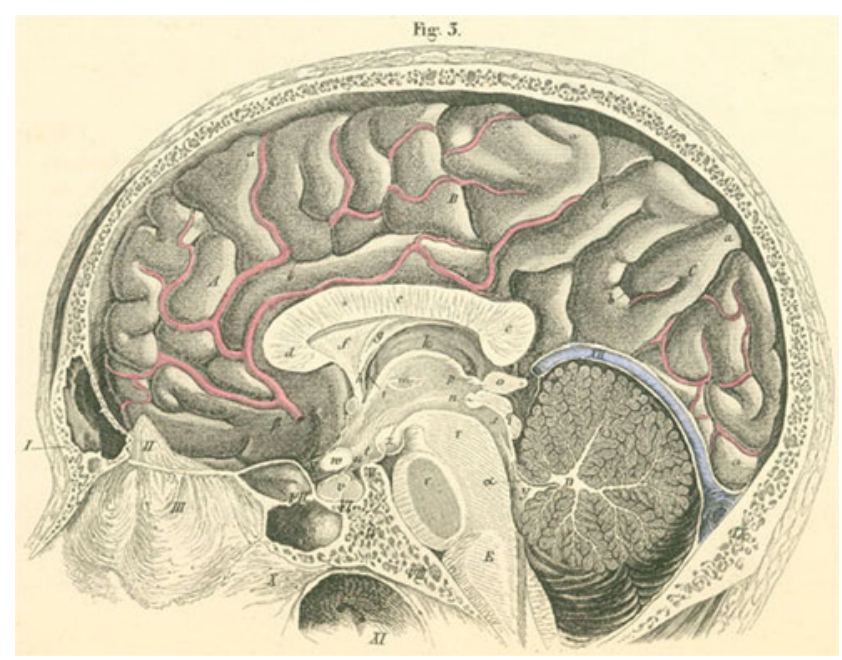

Fig. 4 Sagittal drawing of the brain illustrating the pineal gland $(o)$ from Bock's 19th century Handbuch der Anatomie des Menschen (1841) Leipzig, Germany

of its anatomy. However, even with our improved understanding of the gland, all of its functions have yet to be determined.

\section{References}

1. Albrecht E (2000) Excursus: Aristotle and other Greek and Arabic scientific sources in three thirteenth-century Latin encyclopedias. In: Harvey S (ed) The medieval Hebrew encyclopedias of science and philosophy. Kluwer Academic Publishers, Amsterdam, pp 58-70

2. Aquinas T, transl. Rowan JP (1949) Quaestiones disputatae de anima. B. Herder Book Co., St. Louis. Art. 10

3. Augustine, ed. Knight K (2009) On the trinity, Book 6, chapter 6. http://www.newadvent.org/fathers/130106.htm. Accessed 13 Jul 2010

4. Blavatsky HP (1888) The secret doctrine, vol 2. The Theosophical Publishing Company Ltd, London

5. LeBaron R (1970) Hormones, a delicate balance. Regasus, New York, p 140

6. Lerner AB, Lerner MR (1958) Congenital and hereditary disturbances of pigmentation. Bibl Paediatr 14:308-313

7. Lockhorst GJ, Kaitaro TT (2001) The originality of Descartes' theory about the pineal gland. J Hist Neurosci 10:6-18

8. Lokhorst GJ (2008) Descartes and the pineal gland. Stanford Encyclopedia of Philosophy, http://plato.stanford.edu/entries/pinealgland/. Accessed 13 Jul 2010

9. López-Muñoz F, Marín F, Alamo C (2010) The historical background of the pineal gland: I. From a spiritual valve to the seat of the soul. Rev Neurol 50:50-57

10. López-Muñoz F, Marín F, Alamo C (2010) The historical background of the pineal gland: II. From the seat of the soul to a neuroendocrine organ. Rev Neurol 50:117-125

11. Nemesius (1802) De natura hominis graece et latine. Halle (Greek text with Latin translation). Photographic reprint, Hildesheim; 1967, chapters 6-13

12. Rocca J (2003) Galen on the brain. Brill Academic Press, Leyden

13. Romay G (2004) Pineal gland - bridge of stars. http://www. bridgeofstars.co.uk/pineal-gland.htm. Accessed 13 Jul 2010 
14. Schiller F (1995) Pineal gland, perennial puzzle. J Hist Neurosci 4: 155-165

15. Singer C (1952) Vesalius on the human brain. Oxford University Press, London

16. Smith W (ed) (1880) A dictionary of Greek and roman biography and mythology, vol I. John Murray, London, p 16

17. Smith CU (1998) Descartes' pineal neuropsychology. Brain Cogn 36:57-72

18. Steno N (1965) Nicholaus Steno's lecture on the anatomy of the brain. (Original: Stensen N, 1669.) Introduced by Scherz G. Nyt Nordisk Forlag, Arnold Busch, Copenhagen
19. Strassman R (2010) DMT: the spirit molecule. http://www. rickstrassman.com/?q=node/4. Accessed $13 \mathrm{Jul} 2010$

20. Willis T (1681) The anatomy of the brain and the description and use of the nerves. In: Pordage $S$, translator. The remaining medical works of that famous and renowned physician Dr. Thomas Willis. London, p 125-129

21. Wilson MD (1978) Descartes. Routledge \& Kegan Paul, London

22. Young JZ (1973) The pineal gland. Philosophy 48:70-74

23. Zrenner C (1985) Theories of pineal function from classical antiquity to 1900: a history. Pineal Res Rev 3:1-40 